\title{
HUBUNGAN PENGETAHUAN DENGAN MINAT SUAMI \\ UMUR 30 - 50 TAHUN DALAM MENGGUNAKAN KB MEDIS OPERATIF PRIA (MOP)
}

(Di RT 18 dan 19 RW 3 Dsn Betik, Kelurahan Ngampel, Kecamatan Mojoroto, Kota Kediri)

Betristasia Puspitasari $^{1}$, Duwi Puspitasari ${ }^{2}$

${ }^{1,2}$ Akademi Kebidanan Dharma Husada Kediri Jawa Timur

\begin{abstract}
Abstrak
KB Medis Operatif Pria (MOP) adalah suatu metode kontrasepsi operatif minor pada pria. Rendahnya penggunan kontrasepsi di kalangan pria dipengaruhi oleh persepsi selama ini bahwa progam KB hanya diperuntukan bagi wanita, sehingga pria lebih cenderung pasif. Tujuan penelitian mengetahui hubungan pengetahuan dengan minat suami umur 30-50 tahun dalam menggunakan KB Medis Operatif Pria (MOP).Desain penelitian yang digunakan korelasional dengan pendekatan Cross Sectional. Penelitian dilaksanakan tanggal 25-29 Mei 2017 di RT 18 dan 19 RW 03 Dusun Betik, Kelurahan Ngampel, Kecamatana Mojoroto, Kota Kediri. Populasinya adalah semua suami umur 3050 tahun menggunakan sampling jenuh, sampel penelitianya sebanyak 37 responden. Variabel indepen pengetahuan suami tentang KB Medis Operatif Pria (MOP) diuji dengan kuesioner dan variabel dependen minat suami umur 30-50 tahun dalam menggunakan KB Medis Operatif Pria (MOP) diuji dengan kuesioner. Instrumen penelitian menggunakan kuesioner yang sudah di uji validitas dan uji reliabilitas. Pengolahan data meliputi Coding, Editing, Scoring, Tabulating. Dianalisa dengan chi kuadrat. Hasil penelitian menunjukkan sebagian besar responden berpengetahuan cukup sejumlah $22(59,46 \%)$ dan sebagian besar responden memiliki minat rendah sebanyak 15 (40,54\%). Hasil analisis chi square didapatkan nilai $p$-value $=0,000<0,05$ maka $\mathrm{H}_{1}$ diterima, artinya ada hubungan pengetahuan dengan minat suami umur $30-50$ tahun dalam menggunakan KB Medis Operatif Pria (MOP).Berdasarkan hasil penelitian disimpulkan bahwa semakin baik pengetahuan suami tentang KB Medis Operatif Pria (MOP) maka semakin tinggi minat suami menggunakan KB Medis Operatif Pria (MOP). Diharapkan petugas kesehatan lebih aktif memberikan informasi tentang KB Medis Operatif Pria (MOP), sehingga dapat termotivasi menggunakan KB medis operatif pria (MOP).
\end{abstract}

Kata kunci : Pengetahuan, minat suami umur 30-50 tahun, KB Medis Operatif Pria (MOP)

Korespondensi: Ds. Sidomulyo RT 002/RW 002 Kec. Semen Kab. Kediri Jawa Timur HP: 085790256810 ,email: betristasya@gmail.com 


\section{Pendahuluan}

Indonesia merupakan salah salah satu negara berkembang yang memiliki jumlah penduduk terbesar keempat setelah negara China, India, dan Amerika Serikat. Masalah kependudukan yang dihadapi Indonesia saat ini tidak hanya jumlah penduduk besar dengan laju pertumbuhan penduduk (LPP) yang relative tinggi, tetapi juga penyebaran penduduk yang tidak merata, struktur umur dan kualitas penduduk yang masih rendah. (Sulistyawati, 2011)

Dengan bertambahnya jumlah penduduk di Indonesia, untuk dapat mengangkat derajat dan kehidupan bangsa telah dilaksanakan progam keluarga berencana (KB). KB juga merupakan salah satu cara yang paling efektif untuk meningkatkan ketahanan keluarga, kesehatan, dan keselamatan keluarga.

Berdasarkan UU No.8 tahun 2009, keluarga berencana adalah upaya mengatur kelahiran anak, jarak dan usia ideal melahirkan, mengatur kehamilan, melalui promosi, perlindungan, dan bantuan sesuai dengan hak reproduksi untuk mewujudkan keluarga yang berkualitas. Untuk mewujudkan keluarga berkualitas yang hakekatnya keluarga Indonesia yang mempunyai anak ideal, sehat, berpendidikan, sejahtera, berketahanan, dan terpenuhi hak-hak reproduksinya (Lucky\&Titik, 2015:23).

Macam - macam KB terdiri dari Metode Kontrasepsi Jangka Pendek seperti KB suntik, KB pil, dan Metode Jangka Panjang seperti KB IUD, KB Implant. Adapun macam Kontrasepsi Mantap yaitu KB MOW (tubektomi) dan KB Medis Operatif Pria (MOP). Dalam program Keluarga Berencana, salah satu masalah yang dihadapi saat ini adalah masalah penggunaan MKJP, yaitu KB Medis Operatif Pria (MOP).

KB Medis Operatif Pria (MOP) adalah suatu metode kontrasepsi operatif minor pada pria yang sangat aman, sederhana dan sangat efektif, memakan waktu operasi yang sangat singkat dan tidak memerlukan anastesi umum (Handayani, 2011:167).

Pemerintah telah berupaya untuk meningkatkan kesertaan pria dalam berKB, yang selama ini lebih ditunjukan kepada wanita untuk membantu menekan Laju Pertumbuhan Penduduk (LPP) sebanyak $47,78 \%$, pil sebanyak $23,6 \%$, implant sebanyak 10,58\%, IUD sebanyak $10,73 \%$, kondom sebanyak 3,16\% (Profil Kesehatan Indonesia, 2015: 121).

Di provinsi Jawa Timur tahun 2015 yang menggunakan kontrasepsi suntik sebanyak namun hasilnya masih belum sesuai harapan (BKKBN, 2011).

Para suami banyak menganggap bahwa KB Medis Operatif Pria (MOP) sama dengan pengebirian, dapat menyebabkan kanker, sperma yang tertimbun di dalam tubuh akan menimbulkan efek negative, dan banyak dari mereka yang merasa khawatir bahwa KB Medis Operatif Pria (MOP) dapat menyebabkan kenaikan berat badan dan kelemahan fisik yang membuat mereka berfikir panjang untuk menjadi akseptor. Dari adanya efek samping tersebut sehingga minat kaum pria mengikuti progam Keluarga Berencana masih rendah, mereka masih menganggap tabu bila seorang pria mengikuti progam KB, kurangnya informasi, rendahnya pengetahuan suami, dan masih adanya anggapan bahwa KB urusan perempuan.

Pengetahuan pria yang kurang tentang KB MOP yang memiliki dampak akan mengurangi kejantanan dan takut kurang memuaskan istri serta takut tidak bisa mempunyai anak lagi, menyebabkan minat pria menjadi rendah. Padahal kenyataanya MOP tidak akan mengurangi kejantanan pria tetapi tujuanya agar tidak terjadi pembuahan atau mengikat saluran sel sperma. Beberapa penelitian ahli mengatakan bahwa dari pengakuan akseptor kontrasepsi MOP, mereka sama sekali tidak merasakan adanya efek samping seperti mengurangi kejantananan pasca operasi (Novianti, 2008).

Permasalahan lain yang dihadapi pembangunan bidang kependudukan dan keluarga berencana adalah prevalensi pemakaian kontrasepsi, dan kebutuhan berKB yang tidak/belum terpenuhi, masih rendahnya pria yang menggunakan kontrasepsi, rendahnya pengetahuan pasangan usia subur tentang KB dan kesehatan reproduksi, belum optimalnya pembinaan dan kemandirian peserta KB, masih terbatasnya kapasitas kelembagaan progam KB, masih belum sinergisnya kebijakan pengendalian penduduk (BKKBN, 2010).

Di Indonesia pada tahun 2015 yang menggunakan kontrasepsi MOP sebanyak $0,65 \%$, MOW sebanyak 3,49\%, suntik

$58,4 \%$, pil sebanyak $17,3 \%$, IUD sebanyak $11,4 \%$, implant sebanyak $8,3 \%$, MOW sebanyak $2,1 \%$, MOP sebanyak $0,8 \%$, kondom sebanyak 1,7\% (Dinkes Provinsi Jatim, 2015 : 40).

Berdasarkan pengambilan data dari dinkes kota Kediri pada tahun 2016 didapatkan akseptor aktif 
KB Medis Operatif Pria (MOP) sebesar 94 $(0,3 \%)$.

Berdasarkan laporan dari Puskesmas di Kelurahan Ngampel pada tahun 2017 jumlah PUS 945, yang menjadi akseptor KB MOP 2 akseptor, KB MOW 30 akseptor, KB IUD 74 akseptor, KB Kondom 34 akseptor, KB Pil 81 akseptor, KB lain 2 akseptor.

Rendahnya penggunaan kontrasepsi di kalangan pria dipengaruhi oleh persepsi selama ini bahwa progam KB hanya diperuntukan bagi wanita, sehingga pria lebih cenderung pasif. Hal ini juga nampak dari kecenderungan pengguna tenaga perempuan sebagai petugas dan promoter untuk kesuksesan progam $\mathrm{KB}$, padahal praktik $\mathrm{KB}$ merupakan permasalahan keluarga, dimana permasalahan keluarga adalah permasalahan sosial yang berarti juga merupakan permasalahan pria dan wanita.

Secara psikologi mengikuti progam KB bagi sebagian besar para pria dinilai sebagai tindakan yang asing dan aneh. Jadi tidak ada alasan pria untuk ber-KB, akibatnya tak cukup banyak peserta KB pria hingga saat ini. Sedikitnya peserta pria memang di picu oleh banyak sebab antara lain rumor medis, agama, budaya, dan biaya, hal utama lainnya adalah kampanye dan sosialisasi yang minim (BKKBN, 2012).

Kendala terbesar dalam usaha meningkatkan pencapaian akseptor MOP ini adalah persepsi publik yang keliru. Diantaranya,terdapat informasi yang salah yang menyatakan bahwa KB pria itu membayakan dan semacamnya sehingga minat pria untuk menjadi akseptor sangat rendah (Ratih, 2015).

Pria mengalami kecemasan terhadap kemampuan mereka mencapai orgasme, mempertahankan ereksi, dan perubahan pada ejakulat mereka. Sebagian besar kecemasan mereka dikarenakan mitos bahwa MOP menyebabkan impotensi dan disfungsi seksual. Mereka mungkin juga cemas terhadap kemungkinan kanker prostat dan testis. Beberapa pria mungkin cemas terhadap prosedur dan takut terhadap apa yang mungkin terjadi (Everett, 2008).

Fakta tentang keberhasilan MOP yang sangat efektif untuk mencegah kehamilan sering kali terabaikan karena para suami yang sering kali menjadi korban rumor dan informasi yang salah dan menyebabkan kesalahan persepsi serta berujung dengan keengganan suami untuk menjadi akseptor MOP (Kols, A \& Lande, R. 2008)

Kurang berperannya suami dalam progam Keluarga Berencana dan Kesehatan Reproduksi disebabkan oleh pengetahuan suami mengenai KB secara umum sangat rendah, sehingga minat suami dalam menggunakan KB Medis Operatif Pria (MOP) sangat rendah. Hal ini berdampak besar pada kesehatan reproduksi wanita, karena semua masalah $\mathrm{KB}$ dilibatkan seorang wanita saja.

Pria sebagai kepala keluarga dapat mengambil bagian aktif dalam pelaksanaan KB sehingga dapat dicapai norma keluarga kecil bahagia dan sejahtera (NKKBS). Kebanyakan memiliki pengertian bahwa KB hanya untuk wanita sehingga perencanaan keluarga menjadi pincang. Metode pria yang dapat dipakai adalah memakai kondom, koitus terputus, pantankeluarga berencanag berkala, dan vasektomi sebagai kontap pria (Manuaba, 2009 : 244).

Keikutsertaan dalam progam Keluarga Berencana merupakan tanggung jawab bersama pasangan suami-istri, dan bukannya hanya beban dari isteri saja. Peran serta kaum pria dalam mensukseskan progam nasional keluarga berencana tidak boleh berhenti hanya sampai tahap memberikan ijin kepada isterinya, dan mengantar isterinya pada waktu pelayanan $\mathrm{KB}$ saja. Kaum pria harus juga aktif memanfaatkan pelayanan kontrasepsi khusus bagi pria. Dengan meningkatkan kepedulian para suami terhadap KB akan meningkatkan kesejahteraan keluarga dalam bentuk keluarga kecil yang berkualitas.

Berdasarkan studi pendahuluan pada tanggal 18 April 2017 di RT 18 dan RT 19 RW 03 dusun Betik, Kelurahan Ngampel, Kecamatan Mojoroto, Kota Kediri dilakukan terlebih dahulu terhadap 10 responden dengan wawancara dan mengajukan beberapa pertanyaan tentang $\mathrm{KB}$ Media Operatif Pria (MOP). Diperoleh sebanyak $2(20 \%)$ responden mengerti tentang KB Medis Operatif Pria (MOP).4 (40\%) menganggap bahwa KB Medis Operatif Pria (MOP) adalah pengebirian. Sebanyak $8 \quad(80 \%)$ responden mengatakan kurang mengerti tentang KB Medis Operatif Pria (MOP) dan efek sampingnya. Dari $10(100 \%)$ responden tersebut ternyata tidak ada 
yang berminat menjadi akseptor KB Medis Operatif Pria (MOP) karena takut operasi dan efeksamping KB Medis Operatif Pria (MOP).

Berdasarkan latar belakang diatas peneliti tertarik untuk melakukan penelitian dengan judul" Hubungan Pengetahuan Suami umur 3050 tahun Tentang KB MOP dan Minat suami umur 30-50 tahun Dalam Menggunakan KB Medis Operatif Pria (MOP) di RT 18 dan 19 RW 03 Dusun Betik, Kelurahan Ngampel, Kecamatan Mojoroto, Kota Kediri”.

\section{Metode}

Penelitian ini merupakan . Penelitian korelasional dengan pendekatan Cross Sectional. Populasi pada penelitian ini adalah semua suami umur 30-50 tahun di RT 18 dan 19 RW 03 Dusun Betik Kelurahan Ngampel Kecamatan Mojoroto Kota Kediri sejumlah 37 responden dengan menggunakan teknik sampling jenuh.

\section{Hasil}

\section{Karakteristik Responden}

1) Karakteristik Responden Berdasarkan Umur

\begin{tabular}{|c|c|c|c|}
\hline $\mathrm{NO}$ & Umur ( Tahun ) & Frekuensi & Prosentase \\
\hline 1. & $30-35$ & 6 & 16,22 \\
\hline 2. & $36-40$ & 5 & 13,51 \\
\hline 3. & $41-45$ & 11 & 29,73 \\
\hline 4. & $46-50$ & 15 & 40,54 \\
\hline \multicolumn{2}{|c|}{ Total } & 37 & 100 \\
\hline
\end{tabular}

Berdasarkan tabel diatas dapat diketahui bahwa responden sebagian besar umur 46-50 tahun tahun $(13,51)$. $(40,54)$

\section{2) Karakteristik Responden Berdasarkan Tingkat Pendidikan}

\begin{tabular}{lllc} 
NO & Pendidikan & Frekuensi & Prosentase \\
\hline 1. & SMP & 10 & 27 \\
\hline 2. & SMA & 23 & 62,2 \\
\hline 3. & Akademi / PT & 4 & 10,8 \\
\hline & Total & 37 & 100
\end{tabular}

Berdasarkan tabel dapat diketahui bahwa responden $(10,8 \%)$.pendidikan terakhir sebagian besar responden berpendidikan SMA SMP/MI, dan 12 responden (35,2\%) pendidikan yaitu 23 responden $(62,2 \%)$ dan sebagian kecil terakhir SMA atau sederajat pada tingkat pendidikan Akademi / PT yaitu 4

\section{3) Karakteristik Responden Berdasarkan Pekerjaan}

\begin{tabular}{clcc} 
NO & Pekerjaan & Frekuensi & Prosentase \\
\hline 1. & Swasta & 25 & 67,57 \\
\hline 2. & Buruh & 2 & 5,41 \\
\hline 3. & Wiraswasta & 8 & 21,62 \\
\hline 4. & PNS & 2 & 5,4 \\
\hline & Total & 37 & 100
\end{tabular}

Berdasarkan tabel dapat diketahui bahwa dan sebagian kecil responden adalah PNS yaitu pekerjaan sebagian besar responden adalah sebanyak 2 responden $(5,4 \%)$. swasta yaitu sebanyak 25 responden $(67,57 \%)$ 


\section{4) Karakteristik Responden Berdasarkan Jumlah Anak}

\begin{tabular}{clccc} 
NO & Jumlah Anak & Frekuensi & Prosentase \\
\hline 1. & 2 & 26 & 70,3 \\
\hline 2. & 3 & 10 & 27 \\
\hline 3. & 4 & 1 & 2,7 \\
\hline 4. & $>4$ & & 0 & 0 \\
\hline & & Total & 37 & 100
\end{tabular}

Berdasarkan tabel dapat diketahui bahwa sebagian besar responden memiliki jumlah anak 2 yaitu sebesar 26 responden $(70,3 \%)$ dan sebagian kecil responden memiliki jumlah anak 4 yaitu sebesar 1 responden $(2,7 \%)$.

5) Pengetahuan Suami umur 30-50 tahun Tentang KB Medis Operatif Pria (MOP).

\begin{tabular}{cccc} 
No & Pengetahuan & Frekuensi & Persentase \\
\hline 1. & Baik & 12 & 32,43 \\
\hline 2. & Cukup & 22 & 59,46 \\
\hline 3. & Kurang & 3 & 8,11 \\
\hline & Total & 37 & 100
\end{tabular}

Berdasarkan tabel IV.6 dapat diketahui dari 37 responden sebagian besar didapatkan $22(59,46 \%)$ berpengetahuan cukup dan sebagian kecil berpengetahuan kurang sebesar $3(8,11 \%)$.

6) Minat suami umur 30-50 tahun dalam menggunakan KB Medis Operatif Pria (MOP)

\begin{tabular}{cccc} 
No & Minat & Frekuensi & Persentase \\
\hline 1. & Tinggi & 6 & 16,2 \\
\hline 2. & Sedang & 16 & 43,2 \\
\hline 3. & Rendah & 15 & 40,5 \\
\hline & Total & 37 & 100
\end{tabular}

Berdasarkan tabel dapat diketahui dari 37 responden sebagian besar responden memiliki minat sedang yaitu $16(43,2 \%)$ dan sebagian kecil responden memiliki minat tinggi yaitu sebesar $6(16,2 \%)$.

7) Hubungan pengetahuan dengan minat suami umur 30-50 tahun dalam menggunakan KB Medis Operatif Pria (MOP)

\begin{tabular}{cccccccccc} 
& \multicolumn{1}{c}{ Minat } \\
\cline { 2 - 9 } Pengetahuan & \multicolumn{2}{c}{ Tinggi } & \multicolumn{1}{c}{ Sedang } & \multicolumn{1}{c}{ Rendah } & Jumlah \\
\cline { 2 - 9 } & $\mathrm{N}$ & $\%$ & 16,2 & 6 & 16,2 & 0 & 0 & 12 & 32,4 \\
\hline Baik & 0 & 0 & 10 & 27 & 12 & 32,4 & 22 & 59,5 \\
\hline Cukup & 0 & 0 & 0 & 0 & 3 & 8,1 & 3 & 8,1 \\
\hline Kurang & 6 & 16,2 & 16 & 43,2 & 15 & 40,5 & 37 & 100 \\
\hline Jumlah & &
\end{tabular}

Uji chi square: $\quad$ P-value $=0,000 \quad \alpha=0,05$ 
Berdasarkan tabel dapat diketahui bahwa dari 37 responden hampir setengah responden mempunyai pengetahuan cukup dan memiliki minat rendah dalam menggunakan $\mathrm{KB}$ MOP, yaitu sebanyak $12(32,4 \%)$ dan ada sebagian kecil responden memiliki pengetahuan kurang dan memiliki minat rendah yaitu sebesar 3 responden $(8,1 \%)$.

Berdasarkan hasil analisis chi square didapatkan nilai $p$-value sebesar 0,000 lebih

Diskusi

\section{Pengetahuan Suami Umur 30-50 Tahun Tentang KB Medis Operatif Pria (MOP) di RT 18 dan 19 RW 03 Dusun Betik, Kelurahan Ngampel, Kecamatan Mojoroto, Kota Kediri.}

Berdasarkan tabel pengetahuan suami umur 3050 tahun tentang KB Medis Operatif Pria (MOP) di RT 18 dan 19 RW 03 Dusun Betik, Kelurahan Ngampel, Kecamatan Mojoroto, Kota Kediri dari 37 responden dapat diuraikan bahwa sebagian besar responden memiliki pengetahuan dengan kriteria cukup sebanyak 22 responden $(59,46 \%)$. Pengetahuan adalah merupakan hasil "tahu" dan ini terjadi setelah orang mengadakan pengindraan terhadap suatu objek tertentu. Pengindraan terhadap objek terjadi melalui panca indra manusia yakni penglihatan, pendengaran, penciuman, rasa dan raba dengan sendiri

Wawan dkk, 2011:11).

Pengetahuan tidak dapat muncul dengan sendirinya. Pengetahuan tersebut dapat diperoleh dari orang lain atau pengalamannya sendiri, dalam hasil penelitian ini didapatkan bahwa pengetahuan suami sebagian besar adalah berpengetahuan cukup. Tetapi responden salah mengartikan pengetahuan yang mereka punya sehingga menjadi hambatan untuk melakukan sesuatu yang menurutnya belum tentu benar. Mereka menganggap bahwa KB Medis Operatif Pria (MOP) merupakan jenis pengebirian, dan dapat menyebabkan lemah syahwat. Diantaranya faktor yang mempengaruhi pengetahuan adalah umur, pendidikan, pekerjaan, lingkungan, dan sosial budaya.

Salah satu faktor yang mempengaruhi pengetahuan adalah pendidikan, karena pendidikan untuk menambah dan memperluas pengetahuan. Berdasarkan tabel IV.2 sebagian besar dari 37 responden $23 \quad(62,3 \%)$ berpendidikan SMA.

Pendidikan berarti bimbingan yang diberikan seseorang kepada orang lain agar dapat kecil dari nilai $\alpha$ : $0,05(0,000<0,05)$, sehingga $\mathrm{H}_{1}$ diterima, artinya ada hubungan pengetahuan dengan minat suami umur $30-50$ tahun dalam menggunakan KB Medis Operatif Pria (MOP) di RT 18 dan 19 RW 03 Dusun Betik, Kelurahan Ngampel, Kecamatan Mojoroto, Kota Kediri.

memahami suatu hal. Tidak dapat dipungkiri bahwa semakin tinggi pendidikan seseorang, semakin mudah pula mereka menerima informasi dan pada akhirnya pengetahuan yang dimilikinya akan semakin banyak. Sebaliknya jika seseorang memiliki tingkat pendidikan yang rendah, maka akan menghambat perkembangan sikap orang tersebut terhadap penerimaan informasi dan nilai-nilai yang harus diperkenalkan (Mubarak, $2011: 83$ ).

Dengan pendidikan yang tinggi diharapkan pengetahuan yang telah diperoleh tentang $\mathrm{KB}$ Medis Operatif Pria (MOP) juga tinggi. Seseorang yang pendidikannya rendah belum tentu belum tentu pengetahuanya juga rendah misalnya dalam penelitian ini ada beberapa responden yang pendidikannya rendah akan tetapi pengetahuannya tinggi. Pengetahuan tinggi tidak hanya diperoleh dari pendidikan formal, akan tetapi juga dapat melalui pendidikan non formal. Akan tetapi meskipun pendidikan tinggi, tetapi masyarakat masih banyak yang mempercayai bahwa banyak anak banyak rejeki. Pada tabel IV.4 terdapat 11 responden masih memiliki jumlah anak lebih dari dua yaitu yang memilik jumlah anak 3 sebanyak10 responden (27\%) dan memiliki jumlah anak 4 sebanyak 1 responden $(2,1)$. Dapat disimpulkan bahwa sebagian besar responden banyak yang belum tahu kalau jumlah anak terlalu banyak menurunkan kesehatan reproduksi wanita. Pada kalangan masyarakat dan agama tertentu menganut mitos yang mengatakan banyak "anak banyak rejeki" yang menyebabkan tidak ada kekawatiran bagi pasangan suami istri untuk memiliki banyak anak. Namun demikian sebaliknya secara teori anggapan sebagian masyarakat itu adalah salah karena dipandang dari sisi kesehatan dengan seringnya seorang wanita melahirkan maka semakin besar pula resiko yang didapat untuk terserang penyakit, hal ini dipengaruhi oleh tingkat pendidikan dan 
kondisi sekitar yang mempengaruhi perkembangan dan pengetahuan seseorang.

Dari hasil penelitian ini banyak responden yang berpengetahuan cukup tentang KB Medis Operatif Pria (MOP), maka petugas kesehatan sebaiknya lebih menekankan pemberian informasi atau penyuluhan mengenai KB Medis Operatif Pria (MOP) seperti lebih menekankan petugas PLKB untuk terjun kemasyarakat agar memberikan penyuluhan tentang KB secara optimal misalnya disetiap RT diadakan dalam satu bulan sekali supaya masyarakat lebih mengerti tentang progam KB Medis Operatif Pria (MOP).

\section{Minat Suami Umur 30-50 DAlam Menggunakan KB Medis Operatif Pria (MOP) di RT 18 dan 19 RW 03 Dusun Betik, Kelurahan Ngampel, Kecamatan Mojoroto, Kota Kediri}

Berdasarkan tabel hasil penelitian minat suami umur 30-50 tahun tentang KB Medis Operatif Pria (MOP) di RT 18 dan 19 RW 03 Dusun Betik, Kelurahan Ngampel, Kecamatan Mojoroto, Kota Kediri dari 37 responden dapat diuraikan bahwa sebagian besar responden minat suami umur 30-50 tahun dengan kriteria rendah sejumlah 15 responden $(40,54 \%)$. Dari sini diketahui bahwa suami umur 30 - 50 tahun memiliki minat yang rendah.

Minat adalah suatu rasa lebih suka dan rasa keterikatan pada suatu hal atau aktivitas, tanpa ada yang menyuruh. Minat pada dasarnya adalah penerimaan akan suatu hubungan antara diri sendiri dengan sesuatu diluar diri. Semakin kuat atau dekat hubungan tersebut, semakin besar minat (Slameto, 2013: 180)

Minat seseorang dapat timbul dari diri sendiri, dari pikirannya terhadap sesuatu merupakan keinginan setelah tahu akan sesuatu. Minat yang berasal dari diri sendiri bisa timbul karena suami peduli terhadap kesehatan reproduksi istrinya dan mengurangi beban istrinnya. Sedangkan yang mempengaruhi timbulnya minat dari luar adalah dorongan dari orang lain. Misalnya dukungan dan pembinaan seperti diadakan penyuluhan dan motivasi tentang kelebihan dari KB Medis Operatif Pria (MOP) dari tenaga kesehatan kepada para suami, sehingga membuat para suami mempunyai minat yang tinggi menggunakan KB Medis Operatif Pria (MOP) untuk menjaga kualitas keluarga.

Bedasarkan tabel IV.6 menunjukkan bahwa sebagian besar responden memiliki minat rendah sebanyak 15 responden (40, $54 \%$ ), dalam soal kuesioner minat no. 16 "Menurut saya KB Medis Operatif Pria (MOP) bukan pengebirian alat kelamin" dari 37 responden didapatkan 15 responden (40,54\%) menjawab salah.

Vasektomi adalah metode sterilisasi dengan cara mengikat saluran sperma (vas deferens) pria. Beberapa alternative untuk mengikat saluran sperma tersebut, yaitu dengan mengikat saja, memasang kliptantalum, kauterisasi, menyuntikan sclerotizing agent, menutup saluran dengan jarum, dan kombinasinya (Atika dkk, 2010:68).

Hal ini menunjukkan suami dalam menggunakan KB Medis Operatif Pria (MOP) masih rendah karena adanya persepsi yang salah bahwa KB Medis Operatif Pria (MOP) sama dengan pengebirian. Padahal pengertian dari KB Medis Operatif Pria (MOP) merupakan memotong atau mengikat saluran sperma. Para suami berfikir bahwa dapat mengganggu hubungan seksualnya, sehingga para suami takut akan menggunakan KB Medis Operatif Pria (MOP).

Kurangnya perhatian responden (suami) terhadap istri, sebagian besar suami menyerahkan segala urusan yang berhubungan dengan KB kepada istrinya. Rendahnya penggunaan kontrasepsi di kalangan pria dipengaruhi oleh persepsi selama ini bahwa progam KB hanya diperuntukan bagi wanita, sehingga pria lebih cenderung pasif. Hal ini Nampak dari kecenderungan pengguna tenaga perempuan sebagai petugas dan promoter untuk kesuksesan progam $\mathrm{KB}$, padahal progam $\mathrm{KB}$ merupakan permasalahn keluarga, dimana permasalahan keluarga adalah permasalahan sosial yang berarti permasalahan pria dan wanita.

Motivasi merupakan salah satu indikator yang mempengaruhi minat. Berdasarkan hasil penelitian yang didapatkan sejumlah 37 responden berdasarkan soal kuesioner no.13 mempunyai motivasi rendah untuk menggunakan KB Medis Operatif Pria (MOP) yaitu 16 responden $(43,25 \%)$. 
Menurut (Supriatna, 2009) motivasi merupakan suatu usaha atau pendorong yang dilakukan secara sadar untuk melakukan suatu tindakan dan mewujudkan perilaku terarah demi pencapaian tujuan yang diharapkan dalam situasi interaksi.

Motivasi itu diperoleh dari diri sendiri dan dilakukan secara sadar dalam melakukan suatu tindakan yang menurutnya dianggap benar oleh diri sendiri dan mewujudkan tindakan yang terarah demi mencapai tujuan yang diharapkannya. Sedangkan dorongan atau dukungan dari orang lain suami akan termotivasi untuk menggunakan KB Medis Operatif Pria (MOP). Secara psikologi mengikuti progam KB bagi sebagian besar para pria menilai sebagai tindakan yang asing dan aneh. Jadi tidak ada alas an pria untuk ber-KB, akibatnya tak cukup banyak peserta $\mathrm{KB}$ pria hingga saat ini. Sedikitnya peserta pria memang dipicu oleh banyak sebab antara lain rumor medis, agama, budaya, dan biaya, hal utama lainnya adalah kampanye dan sosialisasi yang minim.

Pengetahuan yang dimiliki suami juga mempengaruhi minat untuk menggunakan KB Medis Operatif Pria (MOP). Dengan adanya faktor psikis dan situasional suami dapat memperoleh informasi tentang $\mathrm{KB}$ Medis Operatif Pria (MOP) dari tenaga kesehatan yang tepat sehingga diharapkan mempunyai minat yang tinggi untuk menggunakan KB Medis Operatif Pria (MOP). Sehingga untuk mengurangi beban seorang istri, mengurangi ledakan penduduk dan meningkatkan kualitas kesehatan reproduksi seorang istri.

\section{Hubungan Pengetahuan Dengan Minat Suami Umur 30-50 Tahun Dalam Menggunakan KB Medis Operatif Pria (MOP).}

Berdasarkan hasil penelitian yang dilakukan didapatkan bahwa ada hubungan pengetahuan tenang KB Medis Operatif Pria (MOP) dengan minat menggunakan KB Medis Operatif Pria (MOP). Hal ini dapat diketahui dari hasil tabulasi silang yang terbanyak yaitu pengetahuan yang cukup tentang KB Medis Operatif Pria (MOP) dengan minat yang rendah untuk menggunakan KB Medis Operatif Pria (MOP) yaitu sejumlah 12 responden $(32,4 \%)$.

Berdasarkan hasil uji chi square didapatkan nilai $\mathrm{p}$ value $=0,000$ lebih kecil dari nilai $\alpha: 0,05 \quad(0,000<0,05)$ dengan taraf signifikan $95 \%$, sehingga $\mathrm{H}_{1}$ diterima, artinya ada hubungan pengetahuan dengan minat suami umur 30-50 tahun dalam menggunakan KB Medis Operatif Pria (MOP) di RT 18 dan 19 RW 03 Dusun Betik, Kelurahan Ngampel, Kecamatan Mojoroto, Kota Kediri.

Ada beberapa faktor yang mempengaruhi pengetahuan antara lain pendidikan, pekerjaan, umur, pengalaman, kebudayaaan, lingkungan sekitar, informasi, dan salah satu faktor lain yang juga mempengaruhi pengetahuan yaitu minat (Mubarak, 2011:83).

Pengetahuan mempunyai hubungan erat dengan minat, yang mana keduanya saling mempengaruhi. Apabila pengetahuan responden tentang KB Medis Operatif Pria (MOP) semakin baik, maka semakin tinggi pula minat responden untuk menggunakan KB Medis Operatif Pria (MOP), begitu juga sebaliknya. Hal ini tentu dipengaruhi oleh beberapa faktor diantaranya yaitu sudah atau belum pernah mendapatkan informasi tentang KB Medis Operatif Pria (MOP) dengan menggunakan KB Medis Operatif Pria (MOP). Semakin responden menyerap dan memahami informasi tersebut, semakin baik pula pengetahuan dan minat yang dimiliki. Tentu saja pemahaman tentang informasi setiap responden berbeda-beda. Responden yang pernah mendapatkan informasi tentang KB Medis Operatif Pria (MOP) maka menimbulkan suatu perubahan pada diri responden tersebut yaitu berminat menggunakan KB Medis Operatif Pria (MOP), sehingga responden akan menambah pengetahuannya semaksimal mungkin.

Berdasarkan soal kuesioner no.3 yaitu "sebenarnya saya sudah mengetahui tentang KB Medis Operatif Pria (MOP), namun saya tidak memakai KB Medis Operatif Pria (MOP)" dari 37 responden $100 \%$ menjawab iya. Dapat disimpulksn bahwa tidak ada responden yang memakai KB Medis Operatif Pria (MOP).

Minat adalah suatu rasa lebih suka dan rasa keterikatan pada suatu hal atau aktivitas, tanpa ada yang menyuruh. Minat pada dasarnya adalah penerimaan akan suatu hubungan antara diri sendiri dengan sesuatu diluar diri. Semakin kuat atau dekat hubungan tersebut, semakin besar minat (Slameto, 2013: 180)

Pengetahuan responden yang cukup tentang KB Medis Operatif Pria (MOP) mempengaruhi minat untuk menggunakan $\mathrm{KB}$ Medis Operatif Pria (MOP). Para suami masih menyerahkan kepada istrinya yang berhubungan dengan KB. Mereka beranggapan bahwa KB adalah tugas seorang perempuan, jadi tidak ada 
alas an bahwa pria menggunakan KB. Minat suami yang rendah terhadap menggunakan KB Medis Operatif Pria (MOP) didukung karena pengetahuan suami yang cukup tentang $\mathrm{KB}$ Medis Operatif Pria (MOP).

Responden yang memiliki pengetahuan cukup dan minat sedang menganggap KB Medis Operatif Pria (MOP) adalah sesuatu yang tabu, padahal ini sangat penting bagi seorang wanita demi menjaga kesehatannya. Sedangkan responden yang mempunyai pengetahuan baik dan minat yang tinggi mereka akan terus berusaha untuk menjadikan pengetahuan yang dimilikinya sebagai suatu kenyataan. Jika responden

benar-benar mengetahui segala sesuatu tentang KB Medis Operatif Pria (MOP) maka akan memiliki minat untuk menggunakannya.

Berdasarkan tabulasi silang menunjukkan dari 37 responden didapatkan sebagian besar responden masuk dalam pengetahuan cukup yaitu $12(32,4 \%)$ dengan minat rendah, dan sebagian kecil responden masuk dalam pengetahuan kurang dengan minat rendah yaitu sebanyak $3(8,1 \%)$.

Hal ini diperkuat Slameto (2010) mengembangkan minat terhadap sesuatu pada dasarnya adalah untuk melihat bagaimana hubungan antara materi yang diharapkan untuk dipelajari dengan diri sebagai individu. Proses ini berarti menunjukkan bagaimana pengetahuan atau kecakapan tertentu dapat mempengaruhi diri dalam hal ini mempengaruhi minat.

Dari data tersebut diketahui bahwa pengetahuan suami tentang KB Medis Operatif Pria (MOP) cukup dengan minat menggunakan KB Medis Operatif Pria (MOP). Minat suami untuk menggunakan KB Medis Operatif Pria (MOP) di pengaruhi oleh pengetahuan yang dimiliki suami tentang KB Medis Operatif Pria (MOP). Sehingga diharapkan petugas kesehatan lebih aktif memberikan penyuluhan dan motivasi untuk menggunakan KB Medis Operatif Pria (MOP) kepada suami. 


\section{Simpulan}

Pengetahuan suami umur 30-50 tahun tentang KB Medis Operatif Pria (MOP) dalam kategori cukup sebanyak 22 responden $(59,46 \%)$.

Minat suami umur 30-50 tahun dalam menggunakan KB Medis Operatif Pria (MOP) dalam kategori rendah sebanyak 15 responden (40,54\%).

Dari analisi uji chi square didapatkan $p$-Value $=$ $0,000<0,05$ dengan taraf signifikan 95\%, maka dapat disimpulkan bahwa $\mathrm{H}_{1}$ diterima artinya ada hubungan pengetahuan dengan minat suami umur 30-50 tahun dalam menggunakan KB Medis Operatif Pria (MOP).

\section{Daftar Pustaka}

Arikunto, Suharsimi. 2013. Prosedur Penelitian Suatu Pendekatan Praktik. Jakarta : Rineka Cipta.

Arum, D.Sujiyatini. 2009. Panduan Lengkap pelayanan KB Terkini.Yogyakarta : Mitra Cendikia.

Budiman. R, Agus. 2014. Kapita Selekta Kuesioner. Jakarta : Salemba Medika.

Handayani, Sri. 2010. Buku Ajar Pelayanan Keluarga Berencana. Yogyakarta : Pustaka Rihama.

Hartanto, Huriawati. 2010. Ragam Metode Kontrasepsi. Jakarta : EGC.

Hidayat, A.Alimul. 2014. Metode Penelitian Kebidanan Dan Teknik analisi Data. Seri 2. Jakarta : Salemba Medika.

Lestari, Titik. 2015. Kumpulan Teori Untuk Kajian Pustaka Penelitian Kesehatan. Yogyakarta : Yogyakarta : Nuha Medika.

Mubarak, Wahit Iqbal. 2011. Promosi Kesehatan untuk Kebidanan. Jakarta: Salemba Medika

Nursalam. 2016. Metodologi Penelitian Ilmu Keperawatan. Jakarta : Salemba Medika.

Notoatmodjo, Soekidjo. 2012. Metodologi penelitian kesehatan. Jakarta : Rineka Cipta.

Prawirohardjo, Sarwono. 2011. Buku Panduan Praktis pelayanan kontrasepsi.Jakarta : Tridasa Printer.

Pinem, Saroha. 2009. Kesehatan Reproduksi dan Kontrasepsi.Jakarta : TIM.

Proverawati, A. Islaely, a. Aspuah, S. 2010. Panduan Memilih kontrasepsi.Yogyakarta : Nuha Medika.

Slameto. 2013. Belajar dan FAktor-Faktor Yang Mempengaruhi. Jakarta : Rineka cipta.

Sulistya, Ari. 2012. Pelayanan Keluarga Berencana.Jakarta : Salemba Medika.

Setiadi. 2013. Konsep dan Praktik Penulisan Riset Keperawatan. Seri2. Yogyakarta : Graha Ilmu.

Setyorini, Anik. 2014. Kesehatan Reproduksi dan Pelayanan Keluarga Berencana.Bogor : In Media.

Suratun, MHRP. et al. Pelayanan Keluarga Berencana dan Pelayanan Kontrasepsi.Jakarta : CV. Trans Info Media.

Jurnal Kebidanan Dharma Husada Vol. 6, No. 1 April 2018| 18 
Suzane, Everett. 2008. Buku Kontrasepsi dan Kesehatan Seksual Reproduktif. Jakarta : EGC.

Uliyah, Mar'atul. 2010. Panduan Aman dan sehat Memilh Alat KB. Yogyakarta : PT Bintang Pustaka abadi (BIPA).

Wawan, A. M. Dewi. 2015.Teori dan Pengukuran, sikap, dan Perilaku Manusia.Yogyakarta : Nuha Medika.

Yuhedi, Lucky. Kurniawati, Titik. 2015. Buku Ajar Kependudukan dan Pelayanan KB. Jakarta : EGC.
Novianti, S. 2014. Faktor Persepsi dan dukungan Istri Yang Berhubungan dengan Partisipasi KB Pria. Journal [online] Vol 02. Diakses dari : http://jurnal.eprintis.ums.ac.id//Nomor2./Faktor/Perse psi /dan/dukungan/istri. [24 Februari-2017].

Wahyu, H. 2010. Hubungan karakteristik Suami dengan Keikutsertaan Suami Menjadi Akseptor KB di wilayah Desa Karangduwur Kec. Petahan, Kab. Kebumen, Jawa Tengah. Journal [online] Vol. 4. [ 01 September 2010] 